Introduction

Researching transgenerationally produces distinctive insights into social experiences and relations over time (Thomson 2014). However, there is a clear deficiency in research when it comes to the experiencing of place by different generations (Hammad 2011). This paper suggests a methodological approach that acknowledges the significance of the generational production of socio-spatial relations; a methodology for the production of knowledge across and within generations that is 'in place' (Murray 2010). We argue that it is through the process of transgenerational walking together in space that significant and original insights can be produced. In doing so, we develop thinking around generation and generational engagements with urban space. We start from the concept of generation, as the basis for conceptual understanding of age as relational, situated in both time and space. Roberts (2012: 480) argues that 'generation' as opposed to 'cohort' relates to transformation, a 'rupture'. The concept of generation can be used, not only as window to future, but as a means to understanding the socio-cultural fixing of practices and identify ways to disrupt this. Generation is, by our definition, dependent on socio-spatial and historical context and transgenerational research holds the potential to challenge ageist assumptions that are premised on un-placed and ahistorical expectations of the ageing body. Here, we consider the body as it walks through time and space, together with other bodies.

According to urbanist de Certeau (1984), the embodied practice of walking creates multiple readings of the city. Whilst these readings tend to be undifferentiated, other scholars (Grosz 1998, Collie 2013) have attended to the gendered and generationed city that produces a different set of readings, based on an alternative set of imprints. The sensory turn in social science brings attention to the senses, to the practice of sensing rather than reading. Sensory ethnography makes it possible to transcend the limitations of language 'seeking the unspoken messages of our bodies and exploring our most intimate relationships' (Classen 2012, xvi). Further, we must look to soundscape studies, which are among the earliest studies using walking both as a scholarly and artistic research method (Westerkamp 1974; Järviluoma and Vikman 2013; McCartney 2014), to find a close focus on both gender and generation. Senses are focal in the never-ending process of walking; 'as place is sensed, senses are placed; as places make sense, senses make place' (Feld 1996: 91). The 'sensory memory walk' deals mostly with gendered, ageing bodies moving in flesh and blood through space and place (Järviluoma 2009b; Järviluoma 2017). However, there has been less attention to the 
specificities of particular socio-culturally marked bodies walking together and creating alternative imprints that arise from their confluence.

This research note considers the methodological implications of the walking body that is differentiated according to generation in tune with other generationed bodies. This approach informs a European Research Council funded project (Sensory Transformations and Transgenerational Environmental Relationships in Europe, 1950-2020: SENSOTRA) ${ }^{1}$ on transgenerational cultural transformations of the sensory between 1950 and 2020. Through a series of transgenerational 'sensobiographic' walks - with a younger person (sometimes a child) and an older person - the project examines changes in and multisensory engagements with local environments. This paper introduces the project and considers the role of generation in determining mobile space and hence determines a rationale for a transgenerational methodological approach. We ask the following questions: How are the bodies of different generations written in mobile space? How does sensory walking with different generations offer particular understandings of mobile space? What new knowledge is created across generational bodies in the process of walking? In considering transgenerational walking as method, it draws from work on intergenerational mobilities (Murray 2015) and sensory commons (Venäläinen 2016) in arguing that looking not only between generations, but to the production of time and space through crossing generations, creates particular understandings in a particular way.

\section{Generational research}

An intergenerational methodological approach requires careful consideration of the concept of generation and its contested use. It can be distinguished from age as it is historio-spatially produced, premised on an impressing of shared time and space; a temporal and spatial commoning that leaves characteristic traces on bodies. Emerging from Mannheim's (1952) seminal work on generation, in which he argued that enduring values and politics are formed at a particular point in the lifecourse, this diverges from generation as a cohort, a group of people of the same age. The categorisation that goes along with 'cohort' is most notable, perhaps, in the work of Strauss and Howe (1991) who defined a series of generational archetypes, including the 'Millennials' that gave rise to other generational categories including, for example, the 'Internet generation' (Milner 2010) and the 'recession generation' (Allen and 
Ainley 2010). However, this attribution of, in particular, values and beliefs, to a group sharing the same period of birth has been widely criticised for its reductive tendencies (Roberts 2012; France and Roberts 2015), and the propensity to generation-blame, for example, through the discourse of 'Boomergeddon' (Bristow 2016: 580). A more critical conceptualisation of generation, which investigates 'the complexities of the contemporary social world alongside understanding the effects of changing conditions for people's sense of self and belonging' (France and Roberts 2015: 218), emerges from a relational approach that interweaves the vertical delineation of generations in families and the historical and spatial situatedness of generation (Thomson 2014).

From studies of generation, then, we derive this focus on change and on the need for an analysis of generational experience - a phenomenological analysis of generation (Embree 2003) where generation is a fluid concept that, in broad terms, incorporates wider social, cultural, spatial and political factors into temporal frames. The importance of this is illuminated in the associations between generation and communication technologies. Generations are often defined in relation to technologies, for example the acceleration of digital technologies being associated with 'millennials' (Roberts 2015). This reductionist approach, however, often casts particular generations as digital leaders or laggers (Murray et al. 2016). The critical methodology adopted here seeks to create knowledge that challenges the ageist assumptions that nourish dominant discourses, particularly around technological capabilities. This can have multiple scholarly impacts, for example, the enrichment of studies on youth and communication technologies through studies of ageing (Loos et al. 2012, Suopajärvi 2015).

Transgenerational refers to the passing across different generations - more often used to refer to the biological transfer of characteristics from parents to children but is also associated with the communication of 'traditions, beliefs and behaviours' from one generation to another (Lieberman 1979). The term has also been used in design since the 1980s (Pirkl 1994). Here our transgenerational methodology is premised on the mobilisation of the term so that it refers to the production of knowledge across generations through shared experience and shared remembering. As Hallam and Ingold $(2007,7)$ have argued, 'following a tradition... is a matter not of replicating a fixed pattern of behaviour, but of carrying on from predecessors.' Hence, the roles played by storytelling and other kinds of narration, arts, and rituals - both religious and non-religious - must also be interrogated. A transgenerational approach invokes 
methodological focus on the sharing of stories and a collective production of knowledge. In doing so it promises knowledge that is distinctive.

\section{Mobilising remembering}

This knowledge production is predicated on memory and remembering. Collective memory theories can be, and have been, criticized for configuring societal and group memories as static, as well as using too static methods (cf. Huyssen 2003, 17): it is through acts of remembering that the past is being produced and mediated (see for example, Järviluoma 2009a.) When a child tells an older family member or some other adult from the immediate neighbourhood about the important paths that he or she is taking, they narrate and produce themselves (see also Formenti et al. 2014). In the analysis of sensory remembering it is important to focus on the ways in which memories are produced in the processes of telling and writing both personal and shared stories. Previous research (Järviluoma 2009a) has attempted to clarify and define the overlapping concepts of social, collective, and cultural memory. We need to take into account the shared frameworks of remembrance even in cases that would by first glance appear to be most personal. Social memory is composed of the memories that are shared by a group, or socially agreed-upon (Misztal 2003, Boym 2001). Connerton (1989, 3) has proposed referring to Marcel Proust - that distinct generations have separate memories, occurring in situations as 'implicit background narratives.' Even if each generation were physically present in the same location, mentally, emotionally, and at the level of their memories, they can be isolated. Thus, a transgenerational perspective focuses on sensing that is culturally and historically situated (Howes 2014, van Campen 2014).

Mobile methodologies are often more strongly focused on the spatial in favour of the temporal. This is not to say that time is forgotten. As well as researching 'in place' (Fincham et al. 2010), considerations of time and temporality has always been integral to thinking after the 'mobilities turn' (Cresswell 2006, Sheller and Urry 2006, Urry 2007). However, there are calls for a greater emphasis on time, which, it is argued has, in its coupling with space, been neglected (Thomson and McLeod 2015). At the same time, a decoupling of time and space can lead to a cannibalizing of the past. The commercialized search for the one and only coherent story of the past means that the versatile paths and interesting discontinuities get lost (see for instance Edensor 2008). The study of social and personal sensory remembering is contingent on the relationality of space and time and a transgenerational approach allows sufficient focus on this. 


\section{Walking as method}

'walking with others or asking others to represent their own experiences through walking offers an inspiring route to understanding' (Pink et al. 2010: 3)

Methodologically, Hammad (2011) is the one of the few scholars to refer to walk-a-longs in connection to intergenerational research. She studied the experiences of home and place that different generations hold in a divided village in Palestine. Here we suggest walking as a means of transgenerational knowledge creation based on a mobile and shared embodied practice that is in communication with the past. The meanings of a space are constructed in the dynamic movement through the space, in which the walkers create a relationship with the space and become its authors (c.f. Saarikangas 2002). In addition, the processes of remembering the past are in motion, in becoming: dynamic, situational, and affected by the individual's moment-bymoment embodied environmental relations and attendant state of mind. (See for example, Järviluoma 2017.)

Generations are in constant re-negotiation in relation to others, to things and to space - made through walking - mediated through technologies in mobile space. Walking is not only a mobile research method (Büscher et al. 2010; Fincham et al 2010; Laurier et al. 2015; Middleton 2011, 2018), but a methodology in itself that has been adopted by a range of disciplines (Kusenbach 2003; Lee an Ingold 2006; Lund 2006; Pierce and Lawhon 2015; Pink et al. 2010; Wylie 2005), including soundscape studies (Westerkamp 1974, Järviluoma 2009b, Järviluoma \& Vikman 2013, McCartney 2014). It has been critiqued as an 'uneven method' (Parent 2016) and methodologies must envision moving together through space in a range of ways, including wheeling. Throughout these methodologies, walking is not simply a movement from one place to another but a practice of engagement with the environment - powerful in communicating across cultural divides (Irving 2007). Walking is also necessarily multisensory (Edensor 2008; Ingold 2000, 2007; Ingold and Vergunst 2008; Pink 2007, 2008, 2009; Lund 2006; Wylie 2005; Kusenbach 2003), engaging a range of senses in the 'the interplay of the visceral and visual' (Pink et al. 2010), and, importantly here, aural. Thus, transgenerational walking here comprises engaging participant pairs composed of different generations in a dynamic multisensory relationship with place, a 'sensobiographic' walk that is visually and aurally recorded and ethnographically observed. This has been inspired by the human geographic concept and methodology of topobiography - the description of the life-course as it relates to lived places (Karjalainen 2009, 31) and by sensory memory walking and 
'commentaried' city walks (2013; see also Järviluoma \& Vikman 2013). In this approach, the conceptual processes of researchers and participants and cases studied are always relational and co-constitutive. The walks take place in three cities: Brighton (UK), Ljubljana (Slovenia), and Turku (Finland), in a 'comparative mobilities' approach where 'local globalness and cities are both relational and territorial', and issues of generation are foregrounded. (Murray et al. 2016, 549)

Generation is in constant renegotiation in relation to others, to things and space - it is made through walking, mediated through technologies - attention to mediations, the process of remembering and sensory commons (cf. Venäläinen's research on 'aural commons' 2016). While acknowledging that sensory biographies are unique and radically singular, the capabilities and 'sensibilities' of sensing are themselves inevitably shared. To make sense of the sensing, we need to refer to common notions - expressions particular to each historical situation - which resonate the experiences of many, rather than only those of a supposedly selfstanding individual. Hence, it will not be a question of concentrating solely on either exceptional skills (such as those of a professional wine taster) or elementary skills (such as distinguishing red from green). Rather, a transgenerational walking methodology addresses the ambiguous middle ground of the sensory commons through which human and planetary coexistence is coordinated (cf. Morton 2010, 47-50, and Venäläinen 2016).

This then leads to a series of questions. Do walkers from different generations create shared understandings of past places? If so, how does this happen, in terms of both verbal recollections and other means of bodily communication, when individuals move as flesh and blood through the streets and fields that used to be significant to them? In addition, what kind of different past and present materialities are the actors in these situations - including smells, sounds, road materials, tastes, spatial arrangements, shoes, vehicles, and different technological devices? The senses are not necessarily receiving data 'only' passively, and speech can also be conceived of as a sense (Classen 1993). Methodologically, this means using both participant and participatory observation alongside the sensobiographic walks. In deep interviews after walks, participants can be encouraged to extend their accounts different aspects of everyday life.

\section{Conclusion}


For de Certeau (1986) everyday spaces are 'enunciative' - walking is an embodied, fundamental and productive experience of the city. De Certeau emphasises the manipulative nature of acts of reading as 'silent productions' that insert the reader's world, histories, pleasures, and body into the author/designer/ administrator's place of the city or the written text: 'words become the outlet or product of silent histories. The readable transforms itself into the memorable...' (xxi). Walking is the practice of the writing of 'unconscious stories' to be 'read' by the walker/researcher in practiced space. The ability to 'read' and make the city, however, requires a level of disengagement, which is not available in equal terms to all bodies (Collie 2013; Murray and Vincent 2014). We are interested in the ways in which generational bodies, ascribed with generational characteristics, sharing walks, transform the city in different ways. In this research note article we have attended to the generationed mobile body. Furthermore, we have taken a step further from generational research, and propose in the spirit of our transgenerational ethnographic and exploratory project SENSOTRA that there is a methodologically based need for ethnographic exploration of what it means to produce knowledge across generations. Attention needs to be focused to mediations, remembering and sensory commons.

Generation is by definition about shared experiences in shared socio-political and historical context. Generations can inhabit the same social space with different practices depending accumulated experience. Generational understandings are also spatial. Conflict or compatibility between generations can produce particular practices and engagements with space. The practices of transgenerational walking are embodied and multi-sensory. They are also emotional experiences. In walking together, experiencing the surrounding environments different generations become interwoven in the shared feeling of space as they pass through it. Their surrounds, their tactility, smells, sights and sounds, the taste of the air, are ever-changing and mutually experienced. They leave traces of their bodies, marked by generation, along the way. The environment is co-enunciated as the bodies pass through and within. But here as bodies are marked by different generational characteristics and experiences, so the embodied responses diverge, converge and morph into a transgenerational tacit understanding of the environment, and distinct knowledge that is produced across generations. When generations walk together and have shared understanding, we can begin to challenge ageist assumptions by understanding why particular groups of people, according to age have a tendency towards, or are considered to exhibit similar characteristics based on shared histories. Walking is about 
bodies moving and making new stories through mediations, through remembering and through shared sensory experiences.

\section{References}

Allen M and Ainley P (2010) Lost generation? New strategies for youth and education. London: Continuum.

Boym S (2001) The future of nostalgia. New York: Basic Books.

Bristow J (2016) The making of 'Boomergeddon': the construction of the Baby Boomer generation as a social problem in Britain. The British Journal of Sociology 67(4): 575-591

Classen C (1993) Worlds of sense: exploring the senses in history and across cultures. London: Routledge.

Classen C (2012) The Deepest Sense: A Cultural History of Touch. Urbana: University of Illinois Press.

Collie N (2013) Walking in the city: urban space, stories and gender. Gender Forum, An internet Journal for Gender Studies 42: 3-14.

Connerton, P. (1989) How societies remember. Cambridge: Cambridge University Press.

de Certeau M (1984) The practice of everyday life. Berkeley: University of California Press.

Edensor T (n.d.) (2008) Walking through ruins. In: Ingold T and Vergunst J (eds), Ways of walking: Ethnography and practice on foot, essay, Aldershot: Ashgate.

Embree L (2003) Generational Phenomenology. Indo-Pacific Journal of Phenomenology 3(1): $1-13$.

Feld S (n.d.) (1996) Waterfalls of Song: An Acoustemology of Place Resounding in Bosavi, Papua New Guine. In: Feld S and Basso KH (eds), Senses of Place, essay, Santa Fe: School of American Research Press, pp. 91-135.

Formenti L, West L and Horsdal M (2014) Embodied narratives: connecting stories, bodies, cultures and ecologies. Odense M: University Press of Southern Denmark.

France A and Roberts S (2014) The problem of social generations: a critique of the new emerging orthodoxy in youth studies. Journal of Youth Studies 18(2): 215-230.

Grosz E (1998) Bodies-cities. In: Pile S and Nast HJ (eds), Places through the body, essay, London: Routledge, pp. 42-51.

Hallam E and Ingold T (2007) Introduction. In: Hallam E and Ingold T (eds) Creativity and cultural improvisation. Oxford: Berg.

Hammad SH (2011) Senses of place in flux: a generational approach. International Journal of Sociology and Social Policy 31(9/10): 555-568.

Howes D (2014) A Cultural History of the Senses in the Modern Age, 1920-2000. London: Bllombury.

Huyssen A (2003) Present pasts: urban palimpsests and the politics of memory. Material Religion 1(2): 272-273.

Ingold T (2000) The perception of the environment: essays on livelihood, dwelling and skill. London: Routledge. 
Ingold T (2007) Lines: A Brief History. London: Routledge.

Ingold T and Vergunst JL (2008) Ways of walking: ethnography and practice on foot. London: Routledge.

Järviluoma H (2017) The Art and Science of Sensory Memory Walking. In: Cobussen M, Meelberg V and Truax B (eds) The Routledge Companion to Sounding Art, essay, London: Routledge, Taylor \& Francis, pp. 191-204.

Järviluoma H (2009a) Soundscape and social memory in Skruv. In: Järviluoma H, Meri K, Truax B, et al. (eds), Acoustic environments in change, essay, Tampere: TAMK in co-operation with Simon Fraser University, pp. $138-153$.

Järviluoma H (2009b) Lesconil - my home. Memories of listening. In: Järviluoma H, Meri K, Truax B, et al. (eds), Acoustic environments in change, essay, Tampere: TAMK in co-operation with Simon Fraser University, pp. 172-193.

Järviluoma H and Vikman N (2013) On Soundscape Methods and Audiovisual Sensibility. In: Gorbman C, Richardson J and Vernallis C (eds) Oxford Handbook of New Audiovisual Aesthetics. Oxford: Oxford University Press, pp. 645-658.

Karjalainen PT (2009) Topobiography: remembrance of places past. Nordia Geographical Publications 38: 5: 31-34.

Kusenbach M (2003) Street phenomenology: The Go-Along as ethnographic research tool. Ethnography 4: 455-85.

Laurier L, Brown B and McGregor M (2016) Mediated Pedestrian Mobility: Walking and the Map App, Mobilities, 11(1): 117-134.

Lee J and T Ingold (2006) Fieldwork on foot: Perceiving, routing, socializing. In Coleman S and Collins P (eds.) Locating the field: Space, place and context in anthropology, Oxford: Berg, pp. 67-86.

Lieberman S (1979) A transgenerational theory. Journal of Family Therapy 1: 347-360

Loos E, Haddon L and Mante-Meijer E (2012) Generational use of new media. Farnham: Ashgate.

Lund K (2006) Seeing in motion and the touching eye: Walking over Scotland's mountains. Anthropological Journal 18 (1): 27-42.

Mannheim K (1952) The Problem of Generations. In Kecskemeti P (ed.) Essays on the Sociology of Knowledge: Collected Works, Volume 5. New York: Routledge, pp. 276-322.

McCartney A (2014) Soundwalking: creating moving environmental sound narratives. In Gopinath S and Stanyek J (eds.) The Oxford Handbook of Mobile Music Studies, Volume 2. $212-237$.

Middleton J (2018) The socialities of everyday urban walking and the 'right to the city'. Urban Studies Vol. 55(2) 296-315.

Middleton J (2011) Walking the city: the geographies of everyday pedestrian practices. Geography Compass, 5(2): 90-105.

Milner H (2010) The internet generation: engaged citizens or political dropouts? Lebanon, NH: University Press of New England.

Misztal B (2003) Theories of social remembering. Maidenhead: Open University Press.

Morton T (2010) The ecological thought. Cambridge, Mass: Harvard University Press. 
Murray L (2015) Age-friendly mobilities: a transdisciplinary and intergenerational perspective. Journal of Transport and health 2 (2): 302-307.

Murray L (2010) Contextualizing and mobilizing research. In: Fincham B, McGuinness M and Murray L (eds.) Mobile Methodologies. Basingstoke: Palgrave Macmillan.

Murray L, Sawchuk K and Jirón P (2016). Comparative mobilities in an unequal world: researching intersections of gender and generation. Mobilities, Special $10^{\text {th }}$ anniversary issue 11 (4): 542-552.

Murray L and Vincent H (2014) Constructing the mobile city: gendered mobilities in London fiction. In Murray $\mathrm{L}$ and Upstone $\mathrm{S}$ Researching and Representing mobilities: transdisciplinary encounters. London: Palgrave Macmillan.

Parent L (2016) The wheeling interview: mobile methods and disability, Mobilities, 11(4): 521-532.

Pierce, J and Lawhon M (2015) Walking as Method: Toward Methodological Forthrightness and Comparability in Urban Geographical Research. The Professional Geographer 67(4): 655662.

Pink S, Hubbard P, O’Neill M, et al. (2010) Walking across disciplines: from ethnography to arts practice. Visual Studies 25(1): 1-7.

Pink S (2007) Walking with video. Visual Studies 22 (3): 240-52.

Pink S (2008) An urban tour. Ethnography 9 (2): 175-96.

Pink S (2009) Doing sensory ethnography. London: Sage.

Pirkl JJ (1994) Transgenerational design: products for an aging population. New York: Van Nostrand Reinhold.

Roberts K (2012) The end of the long baby-boomer generation. Journal of Youth Studies 15(4): 479-497.

Saarikangas K (2002) Merkityksellinen tila [Meaningul space]: lähiöasuminen arkkitehtuurin, asukkaiden, menneen ja nykyisen kohtaamisena. In: Syrjämaa T and TUNTURI J (eds) Eletty ja muistettu tila. [Space Lived and Remembered.] Historiallinen Arkisto 115. Helsinki: Suomalaisen Kirjallisuuden Seura, pp. 48-75.

Sheller M and Urry J (2006) The New Mobilities Paradigm. Environment and Planning A 38: 207-226.

Suopajärvi T (2015) Past experiences, current practices and future design Ethnographic study of aging adults' everyday ICT practices - And how it could benefit public ubiquitous computing design. Technological Forecasting and Social Change, pp. 112-123.

Strauss, W. and Howe, N. (1991) Generations. New York: William Morrow.

Thomson R (2014) Generational research: between historical and sociological imaginations. International Journal of Social Research Methodology, 17 (2). pp. 147-156.

Thomson R and McLeod J (2015) New Frontiers in Qualitative Longitudinal Research: An Agenda for Research. International Journal of Social Research Methodology 18 (3): 243-250.

Urry, J. 2007. Mobilities. London: Routledge.

van Campen, C. The Proust Effect: The Senses as Doorways to Lost Memories. Oxford: Oxford University Press. 
Venäläinen, Juhana (2016) Kuuloyhteisistä kuuntelunvapauteen: kaikupohjia äänimaisemien kestäville käyttökulttuureille. [Aural Commons without Aural Community? Notes on the Political Economy of Soundscapes.], essay. In: Järviluoma $\mathrm{H}$ and Piela $U$ (Eds.) Ä̈nimaisemissa. Helsinki: SKS, pp. 34-52.

Westerkamp H (1974) Soundwalking. Sound Heritage, 3(4).

Wylie JW (2005). A Single Day's Walking: narrating self and landscape on the Southwest Coast Path. Transactions of the Institute of British Geographers, 30(2), 234-247. 